\title{
Tingkat Kelangsungan Hidup Benih Ikan Betok ( Anabas testudineus, Bloch) Yang Dipelihara Dalam Wadah Menggunakan Shellter Dan Tanpa Shellter
}

\author{
${ }^{1}$ Randi Febriansyah , ${ }^{2}$ Muhammad Sugihartono, dan ${ }^{2} \mathrm{M}$. Yusuf Arifin \\ ${ }^{1}$ Alumni Program Studi BudidayaPerairan Fakultas Pertanian, Universitas Batanghari \\ ${ }^{2}$ Program Studi Budidaya Perairan, Fakultas Pertanian Universitas Batanghari \\ Jl. Slamet Riyadi, Broni Jambi. 36122. Telp. +62074160103 \\ ${ }^{1}$ Email korespondensi : randy_f14@yahoo.com
}

\begin{abstract}
Climbing Perch (Testudineus Anabas, Bloch) are Indonesian native fish that live in freshwater and brackish habitats, these Climbing Perch (A. testudineus, Bloch) have a high economic value not only in the form of live fish as consumption purposes, these fish are in the form processed also has a high selling price on the market. The purpose of this study was to determine the growth and survival rates of Climbing Perch Seeds (A. testudineus, Bloch) which were maintained in containers using shellter and without shellter. This study uses 2 different treatments, namely using shellter and without shellter. The seeds of Climbing Perch are then spread into an aquarium with a volume of 54 liters with a density of 3 fish / liter Climbing Perch. The results showed that the maintenance of Climbing Perch using shellter gave the best growth rate and survival of Climbing Perch.
\end{abstract}

Keywords: Climbing Perch, Shellter Technology, Survival, Water Quality

Abstrak. Ikan betok (Anabas Testudineus, Bloch) merupakan ikan asli Indonesia yang hidup pada habitat perairan tawar dan payau, Ikan betok (A. testudineus, Bloch) ini mempunyai nilai ekonomis yang tinggi tidak hanya dalam bentuk ikan hidup sebagai tujuan konsumsi, ikan ini dalam bentuk olahan juga memiliki harga jual yang tinggi di pasar. Tujuan penelitian ini untuk mengetahui tingkat kelangsungan hidup Benih Ikan Betok (A. testudineus, Bloch) yang dipelihara dalam wadah menggunakan shellter dan tanpa shellter. Penelitian ini menggunakan 2 perlakuan yang berbeda yaitu menggunakan shellter dan tanpa shellter. Benih ikan betok kemudian ditebarkan kedalam akuarium dengan volume sebanyak 54 liter dengan kepadatan benih ikan betok 3 ekor/liter. Hasil penelitian menunjukan bahwa pemeliharaan benih ikan betok menggunakan shellter memberikan tingkat kelangsungan hidup benih ikan betok terbaik.

Kata Kunci : Benih Betok, Teknologi Shellter, Kelangsungan Hidup, Kualitas Air

\section{PENDAHULUAN}

Ikan betok (Anabas Testudineus, Bloch) merupakan ikan asli Indonesia yang hidup pada habitat perairan tawar dan payau, Ikan betok (A. testudineus, Bloch) ini mempunyai nilai ekonomis yang tinggi tidak hanya dalam bentuk ikan hidup sebagai tujuan konsumsi, ikan ini dalam bentuk olahan juga memiliki harga jual yang tinggi di pasar (Meidi. A., Sumoharjo., S. W. Asra., M. Ramadhan., D. N. Hidayanto 2015).

Untuk membudidayakan benih ikan betok (A. testudineus, Bloch) bisa dilakukan dikolam atau diakuarium dan didalam pemeliharaan lingkungannya hendaklah menyerupai dengan habitat aslinya. Kebanyakan masyarakat yang membudidayakan ikan betok (A. testudineus, Bloch) ini kurang memahami karakter atau tingkah lakunya. sehingga pembudidaya banyak yang mengalami keluhan dalam pemeliharaan khususnya didalam kelangsungan hidupnya.

Habitat aslinya ikan betok (A. Tetstudineus, Bloch) ini suka hidup bergerombol dan bersembunyi dibawah ranting - ranting kayu, di bawah daun - daun bahkan di dalam lumpur. Sebagai tempat untuk melindungi diri dari serangan predator mau pun tempat untuk istirahat. Oleh kerena itu untuk mengatasi permasalahan di atas perlu upaya pengembangan pemeliharaan benih ikan betok (A. tetstudineus, Bloch). Didalam pengembangan pemeliharaan benih ikan betok (A. tetstudineus, Bloch) bisa menggunakan dengan teknologi shellter. fungsi shellter terhadap kelangsungan hidup untuk ikan adalah sebagai tempat persembunyiannya dari ancaman predator, mengatasi kanibal mau pun sebagai tempat istirahat. Shellter ini bisa berupa ranting kayu, rerumputan, bambu, dan pipa paralon. 
Randi Febriansyah, Muhammad Sugihartono, dan M. Yusuf Arifin. Tingkat Kelangsungan Hidup Benih Ikan Betok ( Anabas Testudineus, Bloch) Yang Dipelihara Dalam Wadah Menggunakan Shellter Dan Tanpa Shellter

Sebagai alternatif pemeliharaan benih ikan betok (A. tetstudineus, Bloch) yang diuji adalah tingkat kelangsungan hidup benih ikan betok (A. testudineus, Bloch) yang dipelihara dalam wadah msenggunakan shellter dan tanpa shellter.

Menurut Saanin (1968) dalam Azrianto (2018), Klasifikasi dan morfologi ikan betok (A. testudineus, Bloch) berdasarkan ilmu taksonomi adalah sebagai berikut:

Kingdom : Animalia

Filum : Chordata

Kelas : Pisces

Sub Kelas : : Teleostei

Ordo : Labyrinthici

Sub Ordo : : Anabantoidei

Famili : Anabantidae

Genus : Anabas

Spesies : : Anabas testudineus, Bloch

\section{METODE PENELITIAN}

Penelitian ini dilaksanakan selama 40 hari pada bulan Maret sampai dengan April tahun 2018. Tempat pelaksanaan penelitian di Balai Benih Ikan Daerah (BBID) Telanai Pura Provinsi Jambi. Shellter yang digunakan dalam penelitian ini adalah paralon yang berukuran 2 inci dengan panjang $10 \mathrm{~cm}$, jumlah shellter dalam satu akuarium sebanyak 5 unit, Dengan tata letak shellter dalam akuarium secara acak. Setelah shellter dimasukan ke akuarium perlakuan, lalu Benih ikan betok ukuran $2-3 \mathrm{~cm}$ dimasukan kedalam akuarium dengan padat tebar 3 ekor/liter air. Volume air setiap akuarium sebanyak 54 liter, jadi jumlah ikan setiap akuarium sebanyak 162 ekor. Sehingga total benih ikan betok yang digunakan sebanyak 1.620 ekor. Selama penelitian berlangsung proses atau penyiponan dan pergantian air dilakukan 2 hari sekali. Parameter yang diamati adalah tingkat kelangsungan hidup merupakan persentase dari jumlah ikan yang hidup dan jumlah ikan yang ditebar selama pemeliharaan (Effendie 1979) dalam Suriansyah (2012), dihitung dengan menggunakan rumus sebagai berikut :

$\mathrm{TKH}=\frac{N_{t}}{N_{0}} X 100 \%$

Keterangan :

$\mathrm{TKH}=$ derajat kelangsungan hidup $(\%)$

$N_{t}=$ jumlah ikan yang ditebar pada awal penelitian (ekor)

$N_{0}=$ jumlah ikan yang ditebar pada akhir penelitian (ekor)

\section{HASIL DAN PEMBAHASAN}

Tingkat Kelangsungan Hidup Ikan Betok ( Anabas testudineus, Bloch)

Berdasarkan hasil pengamatan dan analisis sidik ragam terhadap tingkat kelangsungan hidup benih ikan betok yang di pelihara dalam wadah menggunakan shellter dan tanpa shellter disajikan pada Tabel 1.

Tabel 1. Rerata kelangsungan hidup benih ikan betok (A. tetstudineus, Bloch) yang diberi perlakuan berupa pemeliharaan dengan menggunakan shelter dan tanpa shelter.

\begin{tabular}{ccc}
\hline PERLAKUAN & TKH $(\%)$ & Notasi \\
\hline A & 92,59 & a \\
B & 98,02 & a \\
\hline Keterangan : $\begin{array}{c}\text { angka-angka yang diikuti oleh huruf kecil yang sama menunjukkan berbeda tidak nyata pada } \\
\text { taraf } \alpha \text { 5\%. }\end{array}$
\end{tabular}


Randi Febriansyah, Muhammad Sugihartono, dan M. Yusuf Arifin. Tingkat Kelangsungan Hidup Benih Ikan Betok ( Anabas Testudineus, Bloch) Yang Dipelihara Dalam Wadah Menggunakan Shellter Dan Tanpa Shellter

Berdasarkan hasil analisis sidik ragam pada taraf 5\%. menunjukkan bahwa pemeliharaan benih ikan betok (A. tetstudineus, Bloch) didalam wadah yang menggunakan shellter dan tanpa shellter memberikan pengaruh berbeda tidak nyata terhadap tingkat kelangsungan hidup benih ikan betok (A. tetstudineus, Bloch). Namun demikian, data pada Tabel 1 menunjukkan bahwa benih ikan betok (A. tetstudineus, Bloch) yang dipelihara menggunakan shelter (Perlakuan B) menghasilkan tingkat kelangsungan hidup yang lebih baik.

\section{KESIMPULAN}

Berdasarkan hasil dan penelitian tingkat kelangsungan hidup benih ikan betok (A. testudineus, Bloch) yang dipelihara dalam wadah menggunakan shellter dan tanpa shellter. Dapat ditarik kesimpulan bahwa pemeliharaan benih ikan betok (A. testudineus, Bloch) dalam wadah menggunakan shellter dan tanpa shellter pengaruh yang berbeda tidak nyata terhadap tingkat kelangsungan hidup benih ikan betok ( $A$. testudineus, Bloch). Untuk perlakuan yang terbaik menujukan bahwa tingkat kelangsungan hidup benih ikan betok tertinggi terdapat pada perlakuan B yaitu sebesar 98,02\% selanjutnya diikuti perlakuan A $(92,59 \%)$.

\section{DAFTAR PUSTAKA}

Azrianto., M. Sugihartono., M. Ghofur. 2018. Kelangsungan Hidup Benih Ikan Betok (Anabas testudineus, Bloch) Dengan Debit Air yang Berbeda Pada Sistem Resirkulasi. Jurnal Akuakultur Sungai dan Danau. Vol. 3 No. 1 Tahun 2018 Hal. 12 - 16 ISSN Print 2503-4766 ISSN Online 2597-8837

Effendie, M.I. 1979. Metode Biologi Perikanan. Bogor: Yayasan Pustaka Nusantama.

Meidi, A., Sumoharjo., S. W. Asra., M. Ramadhan dan D. N. Hidayanto. 2015. Pengembangan Pembenihan Ikan Betok (Anabas testudineus) Untuk Skala Rumah Tangga. Jurusan Budidaya Perairan. Fakultas Perikanan dan Ilmu Kelautan. Universitas Mulawarman. Samarinda. Kalimantan Timur. jurnal Media Akuakultur Vol. 10 No. 1. Hal: 31-37

Suriansyah. 2012. Kelangsungan Hidup Larva Ikan Betok (Anabas testudineus Bloch) Dengan Pemberian Pakan Alami Hasil Pemupukan Pada Media Air Gambut. Program Studi Budidaya Perairan Fak. Pertanian Universitas Palangka Raya. Jurnal Ilmu Hewani Tropika Vol 1 No. 2 Desember 2012 